\title{
Making Plaintiffs Whole: The Need for Front Pay Under the ADEA and Other Antidiscrimination Statutes
}

\author{
I \\ INTRODUCTION
}

One of the purposes of remedies in discrimination cases is to compensate victims of discrimination fully for their losses, to make them whole. ${ }^{1}$ To achieve this goal, courts frequently award reinstatement, ${ }^{2}$ seniority, ${ }^{3}$ "back pay," 4 and promotions. ${ }^{5}$ While the remedies available under specific antidiscrimination statutes vary, ${ }^{6}$ the make-whole policy permeates all such statutes.

In addition to the remedies mentioned above, there is another way for courts to compensate employees who have been subjected to discriminatory treatment by their employers. Several courts have recently faced the question of whether "front pay" is an appropriate remedy in cases brought under the Age Discrimination in Employment Act (ADEA). ${ }^{7}$ (The term "front pay" refers to any monetary award for lost wages that will accrue after the date of judgment. ${ }^{8}$ ) These courts have split on whether front pay should ever be

Copyright $@ 1986$ by Law and Contemporary Problems

1. See, e.g., Carey v. Piphus, 435 U.S. 247, 254-55 (1978) (action under 42 U.S.C. $\$ 1983$ ); Franks v. Bowman Transp. Co., 424 U.S. 747, 764 (1976) (Title VII action); Albemarle Paper Co. v. Moody, 422 U.S. 405, 418 (1975) (Title VII action); Johnson v. Railway Express Agency, Inc., 421 U.S. 454, 460, 461 (1975) (action under 42 U.S.C. \& 1981); Sullivan v. Little Hunting Park, Inc., 396 U.S. 229, 238-40 (1969) (action under 42 U.S.C. § 1982); Whittlesey v. Union Carbide Corp., 742 F.2d 724, 728 (2d Cir. 1984) (Age Discrimination in Employment Act (ADEA) action); Miener v. Missouri, 673 F.2d 969, 977 (8th Cir. 1982) (action under $\S 504$ of the Rehabilitation Act of 1973); c.f. Bell v. Hood, 327 U.S. 678, 684 (1946) ("[W] courts may use any available remedy to make good the wrong done." (footnote omitted)).

2. E.g., Kingsville Indep. School Dist. v. Cooper, 611 F.2d 1109 (5th Cir. 1980).

3. E.g., Franks v. Bowman Transp. Co., 424 U.S. 747 (1976).

4. E.g., Albemarle Paper Co. v. Moody, 422 U.S. 405, 421 (1975). The term "back pay" refers to awards of damages made in lieu of lost wages accruing between the discriminatory act and the date of judgment.

5. E.g., Patterson v. American Tobacco Co., 535 F.2d 257, 262, 269 (4th Cir.), cert. denied, 429 U.S. 920 (1976).

6. See, e.g., Johnson v. Railway Express Agency, Inc., 421 U.S. 454, 457-60 (1975) (comparing the remedies available under Title VII with those available under 42 U.S.C. $\$ 1981$ ).

7. 29 U.S.C. $\$$ 621-634 (1982). Generally, the ADEA prohibits discrimination on the basis of age against employees between the ages of 40 and 70 years. 29 U.S.C. $\$ \S 623,631$ (a) (1982).

8. The amount of a front pay award need not be determined on the date of judgment; the court can retain jurisdiction to make periodic awards of back pay. See Patterson v. American Tobacco Co., 535 F.2d 257, 269 (4th Cir.), cert. denied, 429 U.S. 920 (1976). This definition excludes damages for pain and suffering or punitive damages. Such damages are generally considered unavailable under the ADEA. Vazquez v. Eastern Airlines, Inc., 579 F.2d 107 (1st Cir. 1978); Dean v. American Sec. Ins. Co., 559 F.2d 1036 (5th Cir. 1977), cert. denied, 434 U.S. 1066 (1978); Rogers v. Exxon Research \& Eng'g Co., 550 F.2d 834 (3d Cir. 1977), cert. denied, 434 U.S. 1022 (1978). But see infra notes 69-70 and accompanying text. 
awarded ${ }^{9}$ and, if so, under what conditions. ${ }^{10}$ This note examines front pay as a possible remedy in employment discrimination cases, particularly cases brought under the ADEA, and examines the use of front pay in light of the issues raised by recent ADEA cases that address the matter. It then concludes that front pay is an appropriate remedy because it is within the scope of relief authorized by the ADEA, because it fully compensates victims of discrimination, because it removes incentives for discrimination, and because the disadvantages of front pay are insufficient to overcome the benefit of fully compensating victims of discrimination. A number of factors that are relevant to the propriety of awarding front pay in particular cases are discussed in light of this conclusion. Finally, several other antidiscrimination statutes are identified as possible candidates for the application of front pay, and are discussed in the context of issues raised by the use of front pay in ADEA actions.

\section{II}

\section{The State of the Law: Accepted Uses of Front Pay}

\section{A. Awards Under Previous Statutes}

In contrast to the mixed reception that it has been given by courts deciding ADEA cases, as discussed below, front pay is clearly an accepted remedy in certain other types of antidiscrimination cases. ${ }^{11}$ Awards of front pay in these cases are usually granted in two situations: those in which back pay continues after the date of judgment and those in which the plaintiff is not reinstated. Courts have often awarded front pay when the defendant is unable to rectify the discrimination immediately upon a finding of liability. Such situations frequently arise when the defendant has discriminated in granting a promotion, but no higher-level position is available for the plaintiff on the date of judgment. ${ }^{12}$ Front pay has also been awarded in cases in which the employer-employee relationship has ended and reinstatement is

9. See infra notes 19-32 and accompanying text.

10. See infra notes 55-70 and accompanying text.

11. See, e.g., Kingsville Indep. School Dist. v. Cooper, 611 F.2d 1109 (5th Cir. 1980) (action under 42 U.S.C. \$ 1983); White v. Carolina Paperboard Corp., 564 F.2d 1073 (4th Cir. 1977) (action under Title VII and 42 U.S.C. \$ 1981); Patterson v. American Tobacco Co., 535 F.2d 257, 269 (4th Cir.) (Title VII and \& 1981 action), cert. denied, 429 U.S. 920 (1976); Mitchell v. Dyess, 180 F. Supp 852, 854 (S.D. Ala. 1960) (FLSA action).

12. E.g., Patterson v. American Tobacco Co., 535 F.2d 257 (4th Cir.), cert. denied, 429 U.S. 920 (1976). Patterson was brought under Title VII of the Civil Rights Act of 1964, 42 U.S.C. $\$ \S 2000 \mathrm{e}$ to 2000 e- 17 (1982), and under 42 U.S.C. $\$ 1981$ (1982). In Patterson, the court held that the alternative to an award of front pay, to "[allow] senior black and female employees to bump junior employees from preferred jobs," 535 F.2d at 267, ran counter to the interpretation of the Act that prohibits " "the future awarding of vacant jobs on the basis of a seniority system that "locks in" prior racial classification," "id. at 267-68 (quoting Local 189, United Papermakers \& Paperworkers v. United States, 416 F.2d 980, 988 (5th Cir. 1969)) (emphasis in original), and suggested that this inequitable result could be avoided by awarding back pay

for a period commencing at the time the employee was unlawfully denied a position until the date of judgment .... This compensation should be supplemented by an award equal to the estimated present value of lost earnings that are reasonably likely to occur between the date of judgment and the time when the employee can assume his new position. 
impracticable. ${ }^{19}$ These awards of front pay have been made in cases brought under a number of different antidiscrimination statutes, including Title VII of the Civil Rights Act of 1964 (Title VII) ${ }^{14}$ and the Fair Labor Standards Act (FLSA). ${ }^{15}$

In short, front pay is a familiar remedy to courts. In non-ADEA cases it has been used as a continuation of back pay when discrimination cannot be corrected immediately and as an alternative remedy when reinstatement is impractical. Under the ADEA, however, front pay is a disputed remedy. The next section of this note examines this dispute briefly by reviewing recent ADEA cases that have considered front pay awards.

\section{B. Awards Under the ADEA}

The ADEA incorporates by reference ${ }^{16}$ some of the remedies authorized by the FLSA: lost wages, reinstatement, promotions, and liquidated damages. ${ }^{17}$ In addition, the ADEA authorizes a broad range of legal and equitable remedies in order to achieve its purposes. ${ }^{18}$ Acceptance of front pay as a remedy in cases brought under the ADEA, however, has been less than uniform.

Patterson, 535 F.2d at 269 (emphasis added). Front pay was thus a continuation of back pay. In the alternative, the district court was authorized to retain jurisdiction to grant periodic back pay awards until the plaintiffs were promoted. Id. Other cases have followed Patterson by awarding front pay until discrimination has ended. E.g., EEOC v. Safeway Stores, Inc., 634 F.2d 1273, $1281-82$ (10th Cir. 1980) (Title VII action) (front pay was to last until the plaintiff received the transfer he was wrongly denied); Kingsville Indep. School Dist. v. Cooper, 611 F.2d 1109, 1114 (5th Cir. 1980) (action under 42 U.S.C. $\$ 1983$ ) (back pay award covers the period from wrongful termination to effective reinstatement, subject to principles of mitigation); United States v. Lee Way Motor Freight, Inc., 625 F.2d 918, 931-32, 949-50 (10th Cir. 1979) (Title VII action) (trial judge cut off back pay on the date all matters regarding individual relief were settled; the court of appeals remanded with instructions that the judge consider extending back pay until each plaintiff received his rightful position); Hill v. Western Elec. Co., 596 F.2d 99, 104 (4th Cir. 1979) (Title VII action) (upholding an award of front pay for plaintiffs discriminatorily assigned); White v. Carolina Paperboard Corp., 564 F.2d 1073, 1091 (4th Cir. 1977) (action under Title VII and 42 U.S.C. \& 1981) (upholding a front pay award for plaintiffs discriminatorily assigned and denied promotions); James v. Stockham Valves \& Fittings Co., 559 F.2d 310, 358 (5th Cir. 1977) (Title VII action) (instructing the trial judge to consider front pay); EEOC v. Enterprise Ass'n Steamfitters Local No. 638, 542 F.2d 579, 590-91 (2d Cir. 1976) (Title VII action) (trial court erred in cutting off back pay on the date an injunction was issued).

13. E.g., Fitzgerald v. Sirloin Stockade, Inc., 624 F.2d 945, 956-57 \& n.3 (10th Cir. 1980) (Title VIl action); Sabala v. Western Gillette, Inc., 516 F.2d 1251, 1266 (5th Cir. 1975) (Title VII action); Burton v. Cascade School Dist. Union High School No. 5, 512 F.2d 850 (9th Cir. 1975) (action under 42 U.S.C. § 1983); Goldberg v. Bama Mfg. Corp., 302 F.2d 152, 156-57 (5th Cir. 1962) (FLSA action); EEOC v. Kallir, Phillips, Ross, Inc., 420 F. Supp. 919 (S.D.N.Y. 1976) (Title VII action), aff'd mem., 559 F.2d 1203 (2d Cir.), cert. denied, 434 U.S. 920 (1977); Mitchell v. Dyess, 180 F. Supp. 852, 854 (S.D. Ala. 1960) (FLSA action).

14. 42 U.S.C. $\$ \S 2000$ e to $2000 \mathrm{e}-17$ (1982); see cases cited supra note 13.

15. 29 U.S.C. $\$ \S 201-219$ (1982); see cases cited supra note 13.

16. 29 U.S.C. $\$ 626$ (b) (1982); see infra text accompanying note 33.

17. 29 U.S.C. $\$ 216$ (b) (1982); see also infra note 33.

18. 29 U.S.C. $\$ 626$ (c) (1982); see 29 U.S.C. $\$ 626$ (b) (1982); see infra notes $33-34$ and accompanying text. 
To date, six circuits have authorized front pay awards in ADEA cases. ${ }^{19}$ In the most thorough analysis of front pay, the Second Circuit in Whittlesey $v$. Union Carbide Corp. ${ }^{20}$ focused on the ADEA's broad authorization of " 'such legal or equitable relief as may be appropriate to effectuate the purposes of [the ADEA]" "21 to justify front pay. The court also noted the "make whole" purpose of relief under the ADEA and the impossibility of reinstatement in some situations; when reinstatement is impossible, the court reasoned, front pay is necessary to make the plaintiff whole. ${ }^{22}$ The Sixth, Tenth, and Eleventh Circuits have expressly approved front pay for essentially the same reasons as the court in Whittlesey. ${ }^{23}$ The Eighth and Ninth Circuits have both approved front pay in dicta, with virtually no discussion. ${ }^{24}$

One circuit has refused front pay in a specific case without deciding whether it would be available generally. In Wehr v. Burroughs Corp., ${ }^{25}$ the Third Circuit denied front pay when the plaintiff did not desire reinstatement. In the court's view, the plaintiff's desire not to be reinstated eliminated front pay as an issue. ${ }^{26}$

In Kolb v. Goldring, Inc., ${ }^{27}$ the First Circuit flatly denied front pay in all ADEA cases. ${ }^{28}$ This result is surprising in light of the First Circuit's earlier discussion of front pay in Loeb v. Textron, Inc. ${ }^{29}$ In Loeb, the court declined to decide whether front pay is available under the ADEA because the issue had not been well-argued at the appellate level. The court remanded for further consideration by the trial court, implying that front pay is an appropriate remedy. ${ }^{30}$ In Kolb, however, the court stated in a footnote, in dictum, and without discussion, that "damages are 'settled' on the date of judgment and the plaintiff cannot then recover damages for future economic loss, or 'front pay,' even though the injury continues." 11

19. Whittlesey v. Union Carbide Corp., 742 F.2d 724, 728 (2d Cir. 1984); Davis v. Combustion Eng'g, Inc., 742 F.2d 916, 923 (6th Cir. 1984); EEOC v. Prudential Fed. Sav. \& Loan Ass'n, 741 F.2d 1225, 1232 (10th Cir. 1984); O'Donnell v. Georgia Osteopathic Hosp., Inc., 748 F.2d 1543, 1551 (11th Cir. 1984); Gibson v. Mohawk Rubber Co., 695 F.2d 1093, 1100 (8th Cir. 1982); Cancellier v. Federated Dep't Stores, 672 F.2d 1312, 1319 (9th Cir.), cert. denied, 459 U.S. 859 (1982); see also Naton v. Bank of Cal., 649 F.2d 691, 694 (9th Cir. 1981) (affirming, without discussing or deciding, the district court's award of front pay; the front pay award was not an issue in the court of appeals).

20. 742 F.2d 724 (2d Cir. 1984).

21. Id. at 727 (quoting 29 U.S.C. $\$ 626(\mathrm{~b})$ ).

22. Id. at 728 .

23. See Davis v. Combustion Eng'g, Inc., 742 F.2d 916, 923 (6th Cir. 1984); EEOC v. Prudential Fed. Sav. \& Loan Ass'n, 741 F.2d 1225, 1232 (10th Cir. 1984); O'Donnell v. Georgia Osteopathic Hosp., Inc., 748 F.2d 1543, 1551 (11th Cir. 1984).

24. See Gibson v. Mohawk Rubber Co., 695 F.2d 1093, 1100 (8th Cir. 1982) ("The equitable relief that the district court may grant includes inter alia, additional pension benefits, reinstatement, and monetary damages in lieu of reinstatement."); Cancellier v. Federated Dep't Stores, 672 F.2d 1312, 1319 (9th Cir. 1982) ("Damages in lieu of reinstatement may be awarded in addition to liquidated damages.").

25. 619 F.2d 276 (3d Cir. 1980).

26. $I d$. at $283-84$.

27. 694 F.2d 869 (1st Cir. 1982).

28. Id. at 874 n.4.

29. 600 F.2d 1003 (1st Cir. 1979).

30. Id. at 1021-23.

31. 694 F.2d at 874 n.4. 
Although the courts of appeals have tended to approve front pay, district courts remain sharply divided on the issue. ${ }^{32}$ Four circuits, moreover, have not decided the issue. Front pay under the ADEA thus remains an uncertain remedy.

\section{III}

\section{The Availability of Front Pay in ADEa Actions}

\section{A. Reasons for the Use of Front Pay}

In investigating the appropriateness of front pay awards in ADEA cases, the first issue that must be addressed is whether the remedy exceeds the scope of relief authorized by the Act. The Act provides, in part, as follows:

(b) The provisions of this chapter shall be enforced in accordance with the powers, remedies, and procedures provided in sections 211(b), 216 (except for subsection (a) thereof), and 217 of this title, and subsection (c) of this section. Any act prohibited under section 623 of this title shall be deemed to be a prohibited act under section 215 of this title. Amounts owing to a person as a result of a violation of this chapter shall be deemed to be unpaid minimum wages or unpaid overtime compensation for purposes of sections 216 and 217 of this title: Provided, That liquidated damages shall be payable only in cases of willful violations of this chapter. In any action brought to enforce this chapter the court shall have jurisdiction to grant such legal or equitable relief as may be appropriate to effectuate the purposes of this chapter, including without limitation judgments compelling employment, reinstatement or promotion, or enforcing the liability for amounts deemed to be unpaid minimum wages or unpaid overtime compensation under this section.

32. Cases allowing front pay include Koyen v. Consolidated Edison Co., 560 F. Supp. 1161, $1167-69$ (S.D.N.Y. 1983) (superseded by Whittlesey v. Union Carbide Corp., 742 F.2d 724 (2d Cir. 1984)); O'Donnell v. Georgia Osteopathic Hosp., 574 F. Supp. 214, $217-19$ (N.D. Ga. 1982), modified, 748 F.2d 1543 (1lth Cir. 1984); Hoffman v. Nissan Motor Corp., 511 F. Supp. 352, 353-57 (D.N.H. 1981) (apparently superseded by Kolb v. Goldring, Inc., 694 F.2d 869 (1st Cir. 1982)); Pavlo v. Stiefel Laboratories, Inc., 22 Fair Empl. Prac. Cas. (BNA) 489, 494 n.16 (S.D.N.Y. 1979) (superseded by Whittlesey v. Union Carbide Corp., 742 F.2d 724 (2d Cir. 1984)); see also Ginsberg v. Burlington Indus., Inc., 500 F. Supp. 696, 700-01 (S.D.N.Y. 1980) (after weighing the arguments for and against front pay the court assumed it had the authority to grant such relief; front pay was found inappropriate under the circumstances of the case); Robb v. Chemetron Corp., 17 Fair Empl. Prac. Cas. (BNA) 1535, 1545 (S.D. Tex. 1978) (court recognized that there was authority for front pay, but concluded that it was inappropriate in the case before it).

The leading district court case disallowing front pay is Monroe v. Penn-Dixie Cement Corp., 335 F. Supp. 231, 235 (N.D. Ga. 1971); see also Grecco v. Spang \& Co., 566 F. Supp. 413, 415 (W.D. Pa. 1983); Price v. Maryland Casualty Co., 391 F. Supp. 613, 621-22 (S.D. Miss. 1975).

The District Court for Maryland has consistently held that front pay is not available, see Foit v. Suburban Bancorp, 549 F. Supp. 264 (D. Md. 1982); Jaffee v. Plough Broadcasting Co., 19 Fair Empl. Prac. Cas. (BNA) 1194 (D. Md. 1979); Mader v. Control Data Corp., 19 Fair Empl. Prac. Cas. (BNA) 1192 (D. Md. 1978); Covey v. Robert A. Johnston Co., 19 Fair Empl. Prac. Cas. (BNA) 1188, 1191 -92 (D. Md. 1977), despite the Fourth Circuit's decision in Patterson v. American Tobacco Co., 535 F.2d 257 (4th Cir.), cert. denied, 429 U.S. 920 (1976), pioneering front pay in actions brought under Title VII. District courts in the Fifth Circuit are divided on the issue, compare Robb v. Chemetron Corp., 17 Fair Empl. Prac. Cas. (BNA) 1535, 1545 (S.D. Tex. 1978) (allowing front pay) with Price v. Maryland Casualty Co., 391 F. Supp. 613, 621-22 (S.D. Miss. 1975) (disallowing front pay), and courts in the Southern District of New York have solidly supported front pay. See Koyen v. Consolidated Edison Co., 560 F. Supp. 1161, $1167-69$ (S.D.N.Y. 1983); Pavlo v. Stiefel Laboratories, Inc., 22 Fair Empl. Prac. Cas. (BNA) 489, 494 n.16 (S.D.N.Y. 1979); see also Ginsberg v. Burlington Indus., Inc., 500 F. Supp. 696, 700-01 (S.D.N.Y. 1980) (court assumed it had the power to award front pay but found it inappropriate under the circumstances of the case); accord Whittlesey v. Union Carbide Corp., 742 F.2d 724 (2d Cir. 1984). 
(c)(1) Any person aggrieved may bring a civil action in any court of competent jurisdiction for such legal or equitable relief as will effectuate the purposes of this chapter: Provided, That the right of any person to bring such action shall terminate upon the commencement of an action by the Equal Employment Opportunity Commission to enforce the right of such employee under this chapter. ${ }^{33}$

\section{This language is broad enough to include front pay. ${ }^{34}$}

To determine whether front pay should be available under the ADEA, then, it must first be determined whether the remedy will further the purposes of the Act. The express purposes of the ADEA include promoting "employment of older persons based on their ability rather than age" and

33. 29 U.S.C. $\$ 626(b)-(c)$ (1982). Courts frequently state that section 626(b) incorporates FLSA remedies into the ADEA. See, e.g., Wehr v. Burroughs Corp., 619 F.2d 276, 278 (3d Cir. 1980); Grecco v. Spang \& Co., 566 F. Supp. 413, 414 (W.D. Pa. 1983); O'Donnell v. Georgia Osteopathic Hosp., Inc., 574 F. Supp. 214, $216-17$ (N.D. Ga. 1982), modified, 748 F.2d 1543 (11th Cir. 1984); Ginsberg v. Burlington Indus., Inc., 500 F. Supp. 696, 700 (S.D.N.Y. 1980); see also H. REP. No. 805, 90th Cong., 1 st Sess. 5, reprinted in 1967 U.S. Code Cong. \& Ad. News 2213, 2218. This contention is partially true: under $\S 626(\mathrm{~b})$, a violation of the ADEA is a prohibited act under 29 U.S.C. $\$ 215$ (1982); both individuals and a government agency (the Secretary of Labor under the FLSA, 29 U.S.C. § 216(b)-(c) (1982), and the EEOC under the ADEA, 29 U.S.C. $\$ 626(b)$ (1982)) may sue to enforce the acts; and amounts owed employees because of violations of the ADEA are "deemed to be unpaid minimum wages or unpaid overtime compensation for purposes of [the FLSA]." 29 U.S.C. $\S 626$ (b) (1982).

In other ways, though, procedures and remedies under the ADEA differ from those under the FLSA. Before an individual can sue in an ADEA action, he must first give the EEOC 60 days in which to try to resolve the dispute, 29 U.S.C. $\$ 626(\mathrm{~d})$ (1982); FLSA plaintiffs, on the other hand, have no duty to exhaust administrative remedies. The ADEA, unlike the FLSA, cannot be enforced through criminal penalties. Compare 29 U.S.C. $\$ 626$ (b) (1982) with 29 U.S.C. $\$ 216(\mathrm{a})$ (1982). Although liquidated damages are available for ADEA plaintiffs only if they prove a willful violation, see 29 U.S.C. $\$ 626(\mathrm{~b})$ (1982), the FLSA does not require proof of willfulness. 29 U.S.C. $\$ 216(\mathrm{~b})$ (1982). In addition, although injunctive relief is available to private plaintiffs under the ADEA, such relief is not available under the FLSA. Lorillard v. Pons, 434 U.S. 575, 581 (1978). Finally, the FLSA contains no provision comparable to the ADEA's broad authorization of relief under 29 U.S.C. $\$ 626$ (c) (1982). For further discussion of the similarities and differences between the two acts, see generally Lorillard v. Pons, 434 U.S. 575 (1978).

Although attempts have been made to limit ADEA relief to back pay or to the relief available under the FLSA, Blim v. Western Elec. Co., 731 F.2d 1473, 1481 (10th Cir. 1984) (Seth, C.J. concurring and dissenting), this reads limitations into the Act which are in neither the statute nor its legislative history, see infra notes 40-41 and accompanying text, and ignores FLSA case law approving front pay. See, e.g., Goldberg v. Bama Mfg. Corp., 302 F.2d 152, 156-57 (5th Cir. 1962); Mitchell v. Dyess, 180 F. Supp. 852, 854 (S.D. Ala. 1960).

34. As mentioned supra note 33 , this statutory language is broader than the authorization of relief under the FLSA. The breadth of this language can also be contrasted with the language of Title VII, see 42 U.S.C. \$ 2000e-5(g) (1982), which mentions and has been interpreted as creating only equitable remedies, see Great Am. Fed. Sav, \& Loan Ass'n v. Novotny, 442 U.S. 366, 375 (1979); Curtis v. Loether, 415 U.S. 189, 196-97 (1974), despite the award of damages, including front pay, in some cases. See cases cited supra notes 13-15. (This apparent inconsistency may be explained by the characterization of these awards as damages in lieu of reinstatement, which thus retain the equitable character of the remedy of reinstatement.) Although no claim is made here that Title VII remedies cases are authority under the ADEA, it would be anomalous to allow front pay under Title VII but not under the ADEA when the latter expressly authorizes both legal and equitable relief-apparently giving a greater range of possible remedies. Cf. Lorillard v. Pons, 434 U.S. 575, 583-85 (1978) (emphasizing this point). Moreover, because of similar purposes underlying both statutes, and similar factual situations in cases arising under the statutes, the advantages and disadvantages of front pay identified by courts in Title VII actions should correspond substantially to the advantages and disadvantages of front pay in ADEA actions. 
"prohibit[ing] arbitrary age discrimination in employment."35 These purposes are inextricably related. Without a ban on discrimination, employment decisions would continue to be based on age rather than ability. For the ban to be effective, however, the employer must have incentives not to discriminate.

Front pay is necessary to create such incentives. Without front pay, if the victims of discrimination cannot be immediately hired, reinstated, or promoted, the employer can avoid some of the cost of the discrimination: the employer would be liable for back pay to the date of the judgment, but would escape liability for the injury to workers that arises thereafter. The employer would thus have an incentive to continue the discrimination after the judgment by delaying any act of hiring, reinstating, or promoting a victim of age discrimination. With front pay, however, the employer bears the full cost of his discrimination and thus has an incentive to affirmatively end, rather than passively continue, the discrimination.

Front pay is also consistent with the "make-whole" purpose courts have ascribed to the ADEA. ${ }^{36}$ "The Act provides legal and equitable remedies to eliminate the unlawful practices and to restore aggrieved persons to the position where they would have been if the illegal discrimination had not occurred." 37 Front pay is necessary if victims of discrimination are to be made economically whole for their losses. Without front pay, a successful plaintiff is only partially compensated if reinstatement is impossible due to employer animus or if no vacancy exists in the job to which the plaintiff should have been hired, promoted, or assigned.

Whittlesey v. Union Carbide Corporation ${ }^{38}$ epitomizes the need for front pay to make a plaintiff whole. Whittlesey was fired from his position as in-house counsel for Union Carbide because of his age. At the time of the trial, he was about sixty-six years old-four years younger than the legal mandatory retirement age. Reinstatement was impossible because the employer was outraged at Whittlesey for bringing suit against the company. Whittlesey's chances for obtaining similar employment elsewhere were slim, due to his age and high position in the defendant's company. Without front pay, Whittlesey would have lost the salary and benefits he could have earned in the four years before he turned seventy. The court of appeals recognized this and affirmed an award of front pay. "To have denied him compensation for the losses he

35. 29 U.S.C. $\S 621$ (b) (1982). A third statutory purpose, helping employers and workers meet the problems of older workers, is irrelevant to this analysis.

36. See, e.g., Whittlesey v. Union Carbide Corp., 742 F.2d 724, 727-28 (2d Cir. 1984); Dickerson v. Deluxe Check Printers, Inc., 703 F.2d 276, 279 (8th Cir. 1983); Gibson v. Mohawk Rubber Co., 695 F.2d 1093, 1097 (8th Cir. 1982); Rodriguez v. Taylor, 569 F.2d 1231, 1237 (3d Cir. 1977). The statutory provisions for private actions with damages measured by the plaintiff's economic losses, see supra text accompanying note 33; infra text accompanying note 40, suggest that Congress wanted to make victims of age discrimination whole for their economic losses.

37. Gibson v. Mohawk Rubber Co., 695 F.2d 1093, 1097 (8th Cir. 1982).

38. 742 F.2d 724 (2d Cir. 1984). 
would otherwise suffer during those years would have been inconsistent with the Act's purposes." 39

The legislative history of the ADEA also supports the use of front pay. Section 626 refers to "amounts owing" as the monetary relief in an ADEA action. The legislative history of the 1978 amendments to the ADEA explains that " 'amounts owing' . . . includes items of pecuniary or economic loss, such as wages, fringe, and other job-related benefits." 40 The legislative history does not limit "amounts owing" to back wages, but, instead, is silent on the meaning of the word "wages." 41 Because the loss of future wages is as much an economic loss (as opposed to a loss for noneconomic injuries such as pain, suffering, and humiliation) as is the loss of back wages, future wages should clearly qualify for monetary relief under the ADEA.

The preceding discussion illustrates how front pay furthers the purposes of the ADEA. By making employers bear the full cost of discrimination, front pay removes incentives to discriminate. Front pay can achieve the ADEA's purpose of fully compensating plaintiffs in situations in which immediate reinstatement, promotion, or hiring is impossible. As compensation for an economic loss-future wages-front pay is also within the definition of "amounts owing," the Act's term for monetary relief. As relief that "effectuate[s] the purposes of" the ADEA, front pay is thus authorized by the Act in cases where it is appropriate. ${ }^{42}$

\section{B. Countervailing Considerations}

Although front pay promotes the purposes of the ADEA, it is not entirely free from shortcomings. Chief among these shortcomings are the speculative nature of front pay, the availability of more precise remedies, and the possibility that the availability of front pay awards will discourage plaintiffs

39. Id. at 729 .

40. H.R. Conf. Rep. No. 950, 95th Cong. 2d Sess. 13, reprinted in 1978 U.S. Code Cong. \& Ad. News $528,535$.

41. See id.

42. It should be noted that this position has been criticized. Perhaps the most significant opposing opinion was that of Chief Judge Seth in Blim v. Western Elec. Co., 731 F.2d 1473 (10th Cir. 1984), arguing that back pay was the only monetary relief authorized by the ADEA:

It must be recognized that the equitable jurisdiction of a federal court should be flexibly and broadly construed to afford complete relief in light of the statutory purposes ... . However, such equitable powers cannot be used to expand or override the limited legal remedies available under the ADEA. The Congress very clearly distinguishes between the legal and equitable remedies available under the ADEA .... Allowing front pay runs against the intent of Congress in limiting legal remedies to "unpaid wages and unpaid overtime compensation." The court should not use its equitable powers to frustrate the intent of the statute.

Id. at 1481 (Seth, C. J., concurring and dissenting) (citations omitted). This analysis is inadequate. Monetary relief granted under the ADEA is not "unpaid wages and unpaid overtime compensation," but, instead, is for "amounts owing," which are only "deemed to be unpaid wages or unpaid overtime compensation for purposes of" the FLSA. 29 U.S.C. $\$ 626$ (b) (1982) (emphasis added). As has been mentioned above, the loss of future wages is an economic loss clearly within the legislative history's definition of "amounts owing," and compensation for those lost future earnings is clearly within the relief authorized by the ADEA. See supra text accompanying notes 40-41. 
from settling. These drawbacks do not, however, give sufficient justification for completely rejecting the remedy of front pay.

\section{Speculation. Because front pay compensates the plaintiff for future} income, it is inherently imprecise. That is, the exact amount the plaintiff would have earned but for the discrimination cannot be known exactly (or even as precisely as back pay $\left.{ }^{43}\right)$. The possibility of promotions, layoffs, plant closings, normal turnover, and legitimate demotions or dismissals make the amount of future earnings uncertain, and the amount by which the court will err in estimating future earnings will probably exceed its error in estimating back pay.

The imprecision of front pay, however, is not fatal to its usefulness as a remedy. Many ADEA plaintiffs are likely to be near the legal mandatory retirement age. The short time until retirement enables courts to calculate front pay more precisely. Moreover, the plaintiff's tenure with the defendant, which may be quite lengthy, provides a basis for estimating what promotions, demotions, and pay changes the plaintiff would have received had the defendant not discriminated. The plaintiff's general work history, even with other employers, may indicate the likelihood of the plaintiff continuing to work for the defendant until retirement. Furthermore, courts have experience granting front pay in Title VII cases ${ }^{44}$ and lost future wages in tort actions. ${ }^{45}$ If the plaintiff is young, a court could limit the period of front

43. While normally considered easy to measure, back pay awards are, to an extent, imprecise. A court will never know exactly what a plaintiff would have earned from the time of the discriminatory act to the date of judgment. Even looking retrospectively, the court cannot be certain about variables such as how much overtime the plaintiff would have worked or how much work the plaintiff would have missed due to sickness, transportation difficulties, or other problems.

44. E.g., EEOC v. Safeway Stores, Inc., 634 F.2d 1273, 1281-82 (10th Cir. 1980); United States v. Lee Way Motor Freight, Inc., 625 F.2d 918, 931-32, 949-50 (10th Cir. 1979); Patterson v. American Tobacco Co., 535 F.2d 257, 269 (4th Cir.), cert. denied, 429 U.S. 920 (1976).

45. E.g., O'Shea v. Riverway Towing Co., 677 F.2d 1194, 1198 (7th Cir. 1982) (Posner, J.) (admiralty tort action); Fulton v. St. Louis-S.F. Ry., 675 F.2d 1130, 1134 (10th Cir. 1982) (action under the Federal Employer's Liability Act); Kratzer v. Capital Marine Supply, Inc., 490 F. Supp. 222, 230-31 (M.D. La. 1980) (Jones Act action), aff'd, 645 F.2d 477 (5th Cir. 1981); Timmerholm v. Parke Davis \& Co., 285 F. Supp. 432, 453-54 (S.D.N.Y. 1968) (negligence and breach of warranty in the manufacture of a drug).

Indeed, awards of damages for lost future wages in tort actions are common, arising frequently in cases where the plaintiff is permanently incapacitated but not killed by his injuries. In calculation of these damages, an estimate of the plaintiff's earning capacity is made on the basis of his training and the state of his health prior to the injury. The plaintiff's life expectancy, which determines the number of years that he could have expected to work had he not been injured, is calculated on the basis of standard mortality tables, possibly with adjustments made because of the plaintiff's good or poor health prior to the injury or because of a propensity in his family for or against longevity. These figures are used to make a rough determination of the amount of wages that the plaintiff could have been expected to earn in the future. The resulting sum is of course discounted to present value when damages are awarded in a lump sum, in order to prevent gross overcompensation.

It is odd, in light of this institutionalization of future damages awards in negligence actions, that courts in antidiscrimination cases are leery of front pay awards. This judicial reluctance is especially unusual in ADEA actions. The uncertainty of awarding damages for lost future wages to a 21 -yearold plaintiff who is injured in an automobile accident seems almost an order of magnitude higher than the uncertainty involved in awarding damages to a discriminatorily fired 64-year-old plaintiff. In the first case, the aggregate of uncertainty over the long term of years that the plaintiff would have worked but for the accident makes any guess at his expected income sheer science fiction. In the 
pay. ${ }^{46}$ Such a limitation would be arbitrary, but it would reduce the uncertainty and speculative nature of the award. Finally, in spite of the inherent uncertainty in front pay, it is anomalous to penalize the innocent plaintiff for that uncertainty. Because the defendant's illegal discrimination caused the plaintiff's loss, the risk of uncertainty in correcting for this loss justly falls on the defendant. ${ }^{47}$

2. The Availability of More Precise Remedies. Other remedies may achieve the ADEA's purposes of promoting the employment of older workers and making plaintiffs whole without the uncertainty of front pay. Back pay coupled with an order of reinstatement, employment, or promotion is one possibility. "These remedies, explicitly authorized by the statute, involve the least amount of uncertainty because, in effect, they reestablish the prior employment relationship between the parties and at the same time assure the plaintiff of employment free of discrimination based on age."48 Back pay and reinstatement are especially attractive because they enable the plaintiff to continue working, whereas front pay only provides economic compensation. ${ }^{49}$ One weakness of injunctive relief, however, is that the relationship between plaintiff and defendant may be so strained as to prevent a mutually profitable employer-employee relationship from being reestablished. Another is that the employer may not have openings in the job in which the plaintiff should be employed.

A second alternative to front pay is to have the district court retain jurisdiction to make periodic awards of back pay. ${ }^{50}$ At regular intervals, the court could order back pay for the period since its last order. The amount of these periodic awards could be adjusted to reflect some of the contingencies

second example, however, a court may confidently extrapolate the plaintiff's (perhaps extensive) work history over the relatively short time that the award of front pay would be intended to cover. If a court could unflinchingly make an award of damages to the accident victim, any discomfort with a front pay award in the ADEA case is certainly misplaced.

46. E.g., Fitzgerald v. Sirloin Stockade, Inc., 624 F.2d 945 (10th Cir. 1980); EEOC v. Kallir, Phillips, Ross, Inc., 420 F. Supp. 919 (S.D.N.Y. 1976), aff'd mem., 559 F.2d 1203 (2d Cir.), cert. denied, 434 U.S. 920 (1977).

47. In proper cases, front pay should thus be an option. "While . . an award of future damages carries with it some risk of uncertainty and may, indeed, be speculative in some cases, we do not believe the risk to be so great as to preclude automatically front pay in every case." Whittlesey v. Union Carbide Corp., 742 F.2d 724, 728 (2d Cir. 1984).

48. Id.

49. The speeches in Congress about the ADEA reveal great concern about the noneconomic effects of age discrimination on its victims. Representative Eilberg's statement is typical:

The financial and social costs, of course, are nothing compared with the costs in terms of human suffering and welfare which come about as the result of discriminatory practices in employment because of age. Employment plays a very important role in the makeup of the modern American and this role cannot be measured in the dollars he carries home on payday. Self-esteem, self-satisfiction, and personal security are important byproducts of employment in industrial America. To deny a person the opportunity to compete for jobs on the basis of ability and desire, solely because of unfounded age prejudice, is a most vicious, cruel, and disastrous form of inhumanity.

113 Cong. Rec. 34,745 (1967).

50. See, e.g., Patterson v. American Tobacco Co., 535 F.2d 257 (4th Cir.), cert. denied, 429 U.S. 920 (1976). 
that make front pay speculative: legitimate employer layoffs or plant closings; the plaintiff finding other work; a change in the employer's hostile attitude, thereby making reinstatement possible; and the possibility that the plaintiff would have been promoted. By looking into the past rather than into the future, the court has more information from which to calculate monetary relief.

Periodic awards of back pay, however, have two significant disadvantages. The first is the effect on judicial administration. Periodic back pay orders mean that cases must be kept open long after trial. Periodic hearings on the amount of back pay will add to already overcrowded court dockets. Disputes over the procedures for and results of these hearings make interlocutory appeals more likely. If, on the other hand, appellate review is denied until all back pay awards have been made, then the appeal may not come until years after the trial. If a new trial is ordered, the quality of justice at this trial may suffer greatly from the unavailability of witnesses or the unreliability of their memories.

The second disadvantage of periodic back pay awards is the effect of protracted litigation on the parties. Once liability is determined, the parties may be better off going their separate ways rather than having to return to court periodically. The emotional cost of continuously having to face each other could exceed the economic gain from being able to measure the plaintiff's damages more precisely, particularly if the animosity between the parties is great. The finality of front pay may thus both ease the effects of litigation on the courts and allow the parties to continue their lives and put the litigation behind them.

Remedies more precise than front pay may sometimes be available, but they are not free from problems. When reinstatement is not feasible or periodic back pay awards are too burdensome on courts or litigants, front pay provides a means of fully compensating the plaintiff.

3. Effect on Incentives to Settle. One direct effect of front pay awards by courts will be to increase the amount of money flowing to the plaintiff from the defendant when the plaintiff wins. As a result, the settlement value of the case increases. From the plaintiff's perspective, the possibility of a larger damages award raises the amount which the plaintiff will demand before dismissing the case. From the defendant's perspective, front pay increases the amount he will pay to avoid the risk of a greater loss at trial. The increased settlement value, however, may make it harder for the litigants to arrive at a settlement, thereby increasing the number of trials. Front pay has thus been criticized for discouraging settlements. ${ }^{51}$

This possible drawback to front pay should not eliminate it as a remedy in all situations. Although the possibility of a front pay award may increase the settlement value of cases to plaintiffs, this possibility should also increase

51. See Whittlesey v. Union Carbide Corp., 742 F.2d 724, 728-29 (2d Cir. 1984). 
defendants' willingness to settle; the number of trials may not increase. ${ }^{52}$ Moreover, any time damages are authorized or a plaintiff is granted a cause of action, the possibility of success at trial may dampen the plaintiff's willingness to settle. When, however, Congress has created a cause of action and expressly authorized "such legal and equitable relief as may be appropriate to effectuate the purposes" for which the cause of action was created, ${ }^{53}$ it is inappropriate for the courts to second-guess Congress as to whether an otherwise effective and appropriate remedy should be disallowed because it might encourage plaintiffs to assert their rights. As the court in Whittlesey $v$. Union Carbide Corp. noted, "[t]he argument [that plaintiffs will not want to settle] is directed less at front pay as a possible remedy than at the policies underlying the ADEA itself." 54 The passage of the ADEA resolved the question of whether the benefits of allowing private plaintiffs to sue were more important than the additional burden on the courts in favor of allowing the private actions.

\section{IV}

\section{Implications of the Availability of Front Pay in ADEA Cases}

\section{A. Application of Front Pay to Specific Cases}

Although the preceding section concluded that front pay should be an available remedy in appropriate cases, it is clearly not appropriate in every case. Instead, deciding whether front pay should be awarded in a specific case requires another look at the purposes of ADEA.

1. Front Pay Versus Reinstatement. The appropriateness of front pay will usually come under scrutiny when a court is trying to decide between awarding front pay and ordering reinstatement, employment, or a promotion (these options will be referred to collectively as "employment"). Unless the court retains jurisdiction to make periodic back pay awards, ${ }^{55}$ either front pay or an award of employment is necessary to make the plaintiff whole. ${ }^{56}$ Although a district court has some discretion in choosing between front pay and employment, this discretion should be exercised in a way that furthers the purposes of the ADEA. ${ }^{57}$

Other than making plaintiffs whole, the purposes of the ADEA include "promot[ing] employment of older persons based on their ability rather than age." 58 This purpose is furthered by putting victims of age discrimination into the jobs they had or should have had before the discrimination. Thus, an

52. Id.

53. 29 U.S.C. $\& 626$ (b) (1982); see supra text accompanying note 33.

54. 742 F.2d 724, 728 (2d Cir. 1984).

55. See supra note 50 and accompanying text.

56. This analysis assumes that the defendant has not shown that the plaintiff would have been fired or demoted for legitimate reasons (such as a plant closing) between the time of the discriminatory act and the date of judgment.

57. Blim v. Western Electric Co., 731 F.2d 1473, 1478 (10th Cir. 1984).

58. 29 U.S.C. $\$ 621$ (b) (1982). 
order of reinstatement, employment, or promotion is preferable to front pay when both are available.

Reinstatement, however, may not always be available. ${ }^{59}$ The employer may not have a position open in the job to which the plaintiff should be assigned. An order of employment will not fully compensate the plaintiff if the only openings are for jobs below the plaintiff's skill, and hence wage level.60 Forcing the plaintiff to do work beyond his abilities and for which he cannot be trained quickly courts disaster for both the employer and the employee: the employee cannot do the work properly and is thus subject to low evaluations and low self esteem, while the employer suffers from not having the work done correctly. Another option is to demote or fire existing workers, but courts have rejected "bumping" as an option in employment discrimination cases. ${ }^{61}$ This rejection is based, in part, on the availability of back pay and front pay, and on the perceived injustice of having innocent employees bumped. ${ }^{62}$ Thus, when no job is available for the plaintiff, front pay is necessary to make the plaintiff whole.

Reinstatement is also ineffective when hostility between the plaintiff and defendant prevents the establishment of a productive employer-employee relationship. ${ }^{63}$ In such situations, front pay is necessary to make the plaintiff whole. In general, the employer's attitude towards the plaintiff should determine whether the plaintiff can be rehired, not the plaintiff's attitude towards the employer. When the employer is willing to employ the plaintiff, the plaintiff's hostility should not be the cause of the court's order of front pay. If the court were to order front pay in such a situation, the employer, due to the plaintiff's attitude, would be paying both the plaintiff (through front pay) and the worker doing the work the employer is willing to let the plaintiff do. 64

This presumption, however, should be applied with caution. An employer who suddenly indicates a willingness to rehire the plaintiff only after a bitter trial should be viewed with skepticism. The defendant's offer of employment may hide an anger which will doom any employer-employee relationship. The plaintiff's desire not to be reinstated must be considered in light of the relationship between the parties at all stages of the dispute. The plaintiff must mitigate the damages, but he cannot be expected to have Divine forgiveness.

59. Blim v. Western Electric Co., 731 F.2d 1473, 1479 (10th Cir. 1984); see also EEOC v. Prudential Fed. Sav. \& Loan Ass'n, 741 F.2d 1225, 1232 (10th Cir. 1984).

60. A plaintiff might be assigned to such a job temporarily, however, until an appropriate position became available. Front pay would still be necessary, however, to raise the plaintiff's income to the level it would have been without the discrimination.

61. See Spagnuolo v. Whirlpool Corp., 717 F.2d 114, 119-21 (4th Cir. 1983); Patterson v. American Tobacco Co., 535 F.2d 257, 267-69 (4th Cir.), cert. denied, 429 U.S. 920 (1976).

62. Spagnuolo v. Whirlpool Corp., 727 F.2d 114, 120 (4th Cir. 1983); Patterson v. American Tobacco Co., 535 F.2d 257, 269 (4th Cir.), cert. denied, 429 U.S. 920 (1976).

63. E.g., Whittlesey v. Union Carbide Corp., 742 F.2d 724 (2d Cir. 1984); EEOC v. Kallir, Phillips, Ross, Inc., 420 F. Supp. 919 (S.D.N.Y. 1976).

64. Cf. Blim v. Western Elec. Co., 731 F.2d 1473, 1478-79 (10th Cir. 1984); Wehr v. Burroughs Corp., 619 F.2d 276, 283-84 (3d Cir. 1980) (both refusing to grant front pay where the plaintiff was unwilling to accept reinstatement). 
Some uncertainty exists as to whether a request for employment is a prerequisite to an award of front pay. Courts have, on occasion, required the plaintiff to request employment before seeking front pay. ${ }^{65}$ Such a requirement seems unnecessary. A court should award front pay only when reinstatement will be ineffective. Requiring the plaintiff to request employment before receiving front pay could lead the court to conclude erroneously that reinstatement will be effective when, in reality, plaintiffdefendant hostility will prevent the establishment of a productive employeremployee relationship. If, however, the plaintiff requests front pay but the court decides that employment is possible, the court could order reinstatement and let the plaintiff decide whether to take the job. Requiring the plaintiff to prove the appropriateness of front pay and the inappropriateness of employment is a reasonable burden in light of the presumption in favor of employment. ${ }^{66}$ This burden, however, is unrelated to whether the plaintiff has previously requested employment. ${ }^{67}$

\section{Front Pay Versus Remedies Under Other Causes of Action. A plaintiff might} recover damages under a non-ADEA cause of action, such as a breach of contract or wrongful discharge theory. To the extent that damages received under these theories represent lost future earnings, they could be used to reduce a front pay award under the ADEA.

One court has suggested that the availability of statutory liquidated damages should be considered when deciding whether to award front pay in a specific case: "[Where] the value of reinstatement is highly speculative, the availability of a substantial liquidated damages award under the ADEA may be a proper consideration in denying additional damages in lieu of reinstatement."68 This suggestion, however, misconstrues the purpose of liquidated damages. Under the ADEA, "liquidated damages (calculated as an amount equal to the pecuniary loss) ... compensate the aggrieved party for nonpecuniary losses arising out of a willful violation of the ADEA."69 While these nonpecuniary losses are not specified, they clearly do not include lost wages. ${ }^{70}$ Front pay, however, is compensation for lost wages. As such, it is used to make restitution for an economic loss to which the ADEA's provision for liquidated damages was not meant to apply. Front pay and liquidated

65. E.g., Wehr v. Burroughs Corp., 619 F.2d 276, 283-84 (3d Cir. 1980). But see Koyen v. Consolidated Edison, 560 F. Supp. 1161,1169 (S.D.N.Y. 1983).

66. Cf. Fitzgerald v. Sirloin Stockade, Inc., 624 F.2d 945, 957 (10th Cir. 1980) (A Title VII plaintiff need not "request reinstatement as a prerequisite to obtaining front pay where the evidence reveals an atmosphere of hostility.").

67. As a practical matter, the plaintiff could allege in the complaint that reinstatement is inappropriate and pray for front pay.

68. Loeb v. Textron, Inc., 600 F.2d 1003, 1023 n.35 (1st Cir. 1979).

69. H.R. Conf. ReP. No. 950, 95th Cong., 2d Sess. 13-14, reprinted in 1978 U.S. Code Cong. \& AD. News 528, 535.

70. See supra notes $40-41$ and accompanying text. The reference to nonpecuniary losses may mean losses for noneconomic injuries such as pain, mental anguish, and humiliation, which are not directly available under the ADEA. See Rogers v. Exxon Research \& Eng'g Co., 550 F.2d 834, 839-42 (3d Cir. 1977); Dean v. American Sec. Ins. Co., 559 F.2d 1036, 1038-39 (5th Cir. 1977). 
damages compensate a plaintiff for different types of losses, and denying either remedy when both types of loss have occurred will leave the plaintiff less than whole.

In sum, the purposes of the ADEA indicate that orders of reinstatement, employment, or promotion are to be preferred over front pay. The former remedies promote the employment of the plaintiff in addition to making him economically whole. Front pay only makes the plaintiff economically whole without promoting the employment of older workers. Front pay awards could properly be reduced by the recoveries for lost future earnings under nonADEA causes of action, but it is inappropriate to deny front pay because of the availability of liquidated damages under the ADEA.

\section{B. Possible Awards of Front Pay for Violations of Other Antidiscrimination Statutes}

In addition to Title VII and the ADEA, several other federal statutes prohibit employment discrimination; front pay may also offer an effective additional remedy under each. These statutes will be discussed briefly in turn.

1. Reconstruction Era Statutes. Two statutes passed shortly after the Civil War have been interpreted to prohibit employment discrimination. Title 42, section 1981 of the U.S. Code grants all persons the same rights to make and enforce contracts "as is enjoyed by white citizens."7I Individuals injured by violations of the statute may bring private actions for relief. ${ }^{72}$ Although section 1981 claims are often made in connection with Title VII claims for race discrimination, ${ }^{73}$ section 1981 creates a distinct cause of action for which remedies are available in addition to Title VII remedies; ${ }^{74}$ relief may be available under section 1981 even if Title VII does not apply. ${ }^{75}$ "An individual who establishes a cause of action under section 1981 is entitled to both equitable and legal relief, including compensatory and, under certain circumstances, punitive damages."76

71. 42 U.S.C. $\S 1981$ (1982). The entire statute reads as follows:

All persons within the jurisdiction of the United States shall have the same right in every State and Territory to make and enforce contracts, to sue, be parties, give evidence, and to the full and equal benefit of all laws and proceedings for the security of persons and property as is enjoyed by white citizens, and shall be subject to like punishment, pains, penalties, taxes, licenses, and exactions of every kind, and to no other.

72. Johnson v. Railway Express Agency, 421 U.S. 454, 459-60 (1975).

73. See, e.g., Johnson v. Railway Express Agency, 421 U.S. 454, 456 (1975); White v. Carolina Paperboard Corp., 564 F.2d 1073, 1077 (4th Cir. 1977); Allen v. Amalgamated Transit Union Local 788, 554 F.2d 876, 878 (8th Cir. 1977); Patterson v. American Tobacco Co., 535 F.2d 257, 262 (4th Cir.), cert. denied, 429 U.S. 920 (1976).

74. Johnson v. Railway Express Agency, 421 U.S. 454, 461 (1975).

75. For example, section 1981 has no minimum on the number of workers the employer must have before the section applies; Title VII only applies to employers with 15 or more employees. 42 U.S.C. \& 2000e(b) (1982). Also, section 1981 contains no provision for exhausting administrative remedies, as does Title VII. See 42 U.S.C. \& 2000e-5(f)(1) (1982).

76. Johnson v. Railway Express Agency, 421 U.S. 454, 460 (1975). 
The relief available under section 1981 is broad enough to include front pay. Front pay is also consistent with the purpose of section 1981, which was intended "to uproot the institution of slavery and to eradicate its badges and incidents." 77 When a violation of section 1981 results in economic injury, the remedy should place the plaintiff " 'as near as possible in the situation he would have been in had the wrong not occurred.' "78 As under the ADEA, front pay may be necessary to achieve this "make-whole" purpose of section $1981 . .^{79}$

Title 42, section 1983 of the U.S. Code, ${ }^{80}$ another Reconstruction Era statute, also prohibits employment discrimination. Section 1983 makes state officials liable for violations "of any rights, privileges, or immunities secured by the Constitution and laws" when those officials are acting under color of state law. ${ }^{81}$ On its face, section 1983 authorizes private suits for both legal and equitable relief. An action under section 1983 is a type of tort action, ${ }^{82}$ and relief should both compensate the plaintiff and protect the right that was violated. ${ }^{83}$

The compensatory and protective purposes of relief under section 1983 suggest that awards of front pay under the statute are proper. Where reinstatement is impractical ${ }^{84}$ or some time will pass before a plaintiff can be put in his correct position, ${ }^{85}$ front pay will be necessary to compensate him fully. By forcing the employer to bear the full economic cost of his discrimination, further discriminatory treatment is deterred. ${ }^{86}$ Thus, courts should not hesitate to award front pay in section 1983 cases when other remedies are inadequate.

77. Long v. Ford Motor Co., 496 F.2d 500, 504 (6th Cir. 1974).

78. See T \& S Serv. Assocs., Inc. v. Crenson, 666 F.2d 722, 728 (1st Cir. 1981) (quoting Rivera Moreles v. Benitez de Rexach, 541 F.2d 882, 886 (1 st Cir. 1976)).

79. See supra notes $36-39$ and accompanying text.

80. 42 U.S.C. $\$ 1983$ (1982).

81. 42 U.S.C. $\$ 1983$ (1982). In full, the section provides as follows:

Every person who, under color of any statute, ordinance, regulation, custom, or usage, of any State or Territory or the District of Columbia, subjects, or causes to be subjected, any citizen of the United States or other person within the jurisdiction thereof to the deprivation of any rights, privileges, or immunities secured by the Constitution and laws, shall be liable to the party injured in an action at law, suit in equity, or other proper proceeding for redress.

82. Carey v. Piphus, 435 U.S. 247, 253 (1978).

83. See id. at $255,259$.

84. E.g., Burton v. Cascade School Dist. Union High School No. 5, 512 F.2d 850 (9th Cir. 1975). In Burton, a teacher fired for "immorality" was awarded one-half year's salary in addition to the salary due under her contract. Id. at 851. The court determined that reinstatement would have been unduly disruptive to "the school district, the school's staff, the student body, and the community in light of the long standing nature of the controversy." Id. at 853. The front pay seems to have been improperly awarded in this case, however, because reinstatement would have better protected the plaintiff's right not to be fired for an unconstitutionally vague reason.

85. See, e.g., Kingsville Indep. School Dist. v. Cooper, 611 F.2d 1109, 1114 (5th Cir. 1980) (teacher would have to wait until the next school year to be reinstated).

86. See supra p. 245. 


\section{Statutes Applicable to Employers Receiving Federal Funds.}

a. Title IX. Title IX of the Education Amendments of 1972 prohibits sex discrimination in educational programs and activities receiving federal funds. ${ }^{87}$ Although not explicit, Title IX creates a private cause of action for discrimination in employment. ${ }^{88}$

The Supreme Court has not expressly decided what remedies may be used in Title IX cases, but lost wages, including front pay, are probably available. Under Title VI of the Civil Rights Act of $1964,{ }^{89}$ back pay is available. ${ }^{90}$ While Title VI remedies are not expressly applicable in Title IX cases, the virtually identical language of the statutes has resulted in similar interpretation by courts. ${ }^{91}$ The availability of monetary relief in the form of back pay and the principle that federal courts should use all available remedies to provide complete relief to injured persons ${ }^{92}$ indicate that, in appropriate cases, front pay should also be available under Title IX.

Existing Title IX doctrine also supports front pay awards. "Title IX, like its model Title VI, sought to accomplish two related, but nevertheless somewhat different, objectives. First, Congress wanted to avoid the use of federal resources to support discriminatory practices; second, it wanted to provide individual citizens effective protection against those practices." 93 Liability for damages, including front pay, will help protect individuals by creating incentives to end discrimination. Injunctive and declaratory remedies, with only prospective applicability, create no incentive for a school to end discrimination before being sued, an event which may never occur. Liability for damages (including front pay), however, provides an incentive for schools to end discrimination before a suit is brought. ${ }^{94}$

87. 20 U.S.C. $\$ \S 1681-1686$ (1982). The Act provides in part that "[n]o person in the United States shall, on the basis of sex, be excluded from participation in, be denied the benefits of, or be subjected to discrimination under any education program or activity receiving Federal financial assistance . . ." 20 U.S.C. $\$ 1681$ (a) (1982).

88. North Haven Bd. of Educ. v. Bell, 456 U.S. 512, 524-35 (1982). The existence of a private cause of action under Title IX was first recognized in Cannon v. University of Chicago, 441 U.S. 677, 709 (1979).

89. 42 U.S.C. $\S \S 2000 \mathrm{~d}$ to $2000 \mathrm{~d}-6$ (1982).

90. Consolidated Rail Corp. v. Darrone, 465 U.S. 624, 630 (1984).

91. Title VI states that "[n]o person in the United States shall, on the ground of race, color, or national origin, be excluded from participation in, be denied the benefits of, or be subjected to discrimination under any program or activity receiving Federal financial assistance." 42 U.S.C. $\$ 2000 \mathrm{~d}$ (1982). Title VI provided the linguistic pattern for Title IX, Cannon v. University of Chicago, 441 U.S. 677, 694-703 (1979), and the two titles are "companion[s]." Id. at 699.

92. [W] here federally protected rights have been invaded, it has been the rule from the beginning that courts will be alert to adjust their remedies so as to grant the necessary relief. And it is also well settled that where legal rights have been invaded, and a federal statute provides for a general right to sue for such invasion, federal courts may use any available remedy to make good the wrong done.

Bell v. Hood, 327 U.S. 678, 684 (1946) (footnotes omitted); accord Sullivan v. Little Hunting Park, Inc., 396 U.S. 229, 239 (1969) ("The existence of a statutory right implies the existence of all necessary and appropriate remedies.").

93. Cannon v. University of Chicago, 441 U.S. 677, 704 (1979).

94. See supra p. 145. 
b. Rehabilitation Act of 1973. Section 504 of the Rehabilitation Act of $1973^{95}$ forbids discrimination on the basis of handicap in programs receiving federal financial assistance. The language of section 504 is virtually identical to that of Title IX and Title VI,96 and section 504 is enforced through " $[t]$ he remedies, procedures, and rights set forth in Title VI."97 Individuals may enforce section 504 through private suits, and back pay is an available remedy. ${ }^{98}$

The purpose of the Rehabilitation Act is "to develop and implement ... comprehensive and coordinated programs of vocational rehabilitation and independent living."99 The Act assumes that this purpose will be achieved in several ways, including "the guarantee of equal opportunity."100 Front pay helps guarantee equal opportunity. By making the employer liable for all the costs of his discrimination, front pay deters discrimination. ${ }^{101}$ When reinstatement, employment, or promotion is impossible or must be delayed, front pay helps insure that the employer, not the employee, will bear the financial loss. In such circumstances, front pay poses no difficulties under section 504 that courts have not already resolved under Title VII. Finally, front pay under section 504 will make plaintiffs whole, a purpose some courts have ascribed to the Rehabilitation Act. ${ }^{102}$

\section{Conclusion}

Twenty years after the ADEA was enacted, the availability of front pay as a remedy in ADEA cases remains disputed. Although courts of appeals that have considered the issue have generally accepted the remedy (with one exception), there is considerable disagreement among the district courts. Part of this disagreement may be attributed to the confusing language of the ADEA and the uncertain extent of the remedies available under that language. Another part of the disagreement stems from differences in judicial willingness to award damages for losses which will occur in the future. Any reluctance on this point is surprising, however, because courts have

95. 29 U.S.C. \& 794 (1982).

96. Section 504 provides that "[n]o otherwise qualified handicapped individual in the United States, . . . shall, solely by reason of his handicap, be excluded from the participation in, be denied the benefits of, or be subjected to discrimination under any program or activity receiving Federal financial assistance . . ." 29 U.S.C. \& 794 (1982). Compare id. with 20 U.S.C. $\$ 1681$ (a) (1982) (Title IX) and 42 U.S.C. $\$ 2000 \mathrm{~d}$ (1982) (Title VI). These statutes are reprinted supra notes 87, 91.

97. 29 U.S.C. $8794(\mathrm{a})(2)(1982)$.

98. See Consolidated Rail Corp. v. Darrone, 465 U.S. 624, 630 \& n.7 (1984).

99. 29 U.S.C. 8701 (1982).

100. Id.

101. See supra p. 145.

102. See Patton v. Dumpson, 498 F. Supp. 933, 939 (S.D.N.Y. 1980) ("Where, as here, money damages are the only means of compensating a victim of past discrimination, that remedy must be available to the plaintiff. Thus, absent an expression of congressional intent to the contrary, private actions under $\$ 504$ cannot be limited to equitable relief."). 
previously had very little trouble in awarding damages for loss of future wages in negligence actions. ${ }^{103}$

The uncertainty inherent in awards of damages for future losses and the problems caused by a confusing statute, however, are not fatal to front pay in ADEA cases. On its face, the ADEA authorizes any legal or equitable relief needed to achieve its purposes, and neither the Act nor its legislative history limits lost wages to back pay. Moreover, while damages for future losses are inherently speculative, they are not necessarily so speculative as to preclude front pay in appropriate cases. Courts have often awarded front pay in nonADEA employment cases, and damages in tort actions often include reimbursement for future losses.

In addition to promoting the ADEA's objective of fully compensating victims of discrimination, front pay removes incentives for age discrimination. Without front pay, the employer's liability is limited to back pay and reinstatement. Where reinstatement is impracticable, as where animosity between the plaintiff and defendant prevents a resurrection of a productive employment relationship, denial of front pay leaves an employee without an effective remedy and encourages the employer to discriminate unlawfully without any serious threat of legal sanction.

Although front pay is thus a remedy which should be available in ADEA actions, the availability of the remedy in a given case will depend on the particular circumstances that engendered the suit. The employee's characteristics, the availability of other remedies, and other facts surrounding the litigants' current situation should all be considered by a court in deciding whether to grant a front pay award.

What may ultimately be more important, however, than the judicial recognition of the availability of front pay in actions brought under the ADEA is the possibility of even wider use of the remedy. The advantages that make front pay an attractive remedy in some ADEA cases, and the only appropriate remedy in others, also make the remedy attractive and appropriate under other antidiscrimination statutes. Front pay is often the only means of properly effectuating the policy of making discriminatees whole that pervades the entire spectrum of federal antidiscrimination legislation.

103. See supra note 45 and accompanying text. 
. 